\title{
Expression of uterine and cervical epithelial cadherin during relaxin-induced growth in pigs
}

\author{
P. L. Ryan*, D. L. Baum, J. A. Lenhart, K. M. Ohleth \\ and C. A. Bagnell ${ }^{+}$ \\ Department of Animal Sciences, Rutgers, The State University of New Jersey, \\ New Brunswick, NJ 08901-8525, USA
}

\begin{abstract}
Epithelial cadherin (E-cadherin), a member of the cadherin family of calcium-dependent adhesion molecules, is present in reproductive tissues. Relaxin, a hormone important for uterine and cervical growth in pigs, increases the expression of E-cadherin in the MCF-7 mammary epithelial cell line. The objective of this study was to characterize the expression of E-cadherin during relaxin-induced growth of the uterus and cervix in an immature pig model, independent of high circulating steroids. After administration of relaxin to prepubertal gilts, the uterus and cervix were collected. E-cadherin mRNA and protein were measured by northern and western blot analysis, respectively. A $120 \mathrm{kDa}$ protein band, corresponding to E-cadherin, was detected in all tissues examined. Relaxin significantly $(P<0.05)$ increased the amount of E-cadherin protein in the uterus $(P<0.05)$, whereas no significant changes were observed
\end{abstract}

in E-cadherin protein in the cervix. A $4.2 \mathrm{~kb}$ E-cadherin transcript was detected in all tissues and E-cadherin mRNA was significantly higher $(P<0.05)$ in uteri from relaxintreated gilts compared with control gilts. E-cadherin was localized by immunocytochemistry to the epithelial cells of the uterine and cervical lumen, and the uterine glandular epithelium. Quantitative analysis revealed that administration of relaxin significantly increased $(P<0.05)$ the height of the uterine luminal epithelium compared with that of the controls. This is the first report of the expression of E-cadherin in the uterus and cervix of pigs. The findings from this study indicate that relaxin increases the expression of uterine E-cadherin in the reproductive tract of pigs. Administration of relaxin to prepubertal gilts in vivo increased uterine epithelial cell growth independent of circulating steroids, with a concomitant increase in E-cadherin expression.

\section{Introduction}

The reproductive tract is one of the few tissues in the adult that undergoes extensive morphological development and tissue restructuring on a cyclical basis. The events that lead to tissue restructuring are controlled by hormones. Cell adhesion molecules are surface glycoproteins that mediate cell-cell recognition and adhesion essential for normal morphology and maintenance of tissue integrity. Two of the major classes of adhesive receptors expressed by epithelial cells are integrins (Hynes, 1992), which mediate adhesion to extracellular matrix proteins, and cadherins, which mediate cell-cell adhesion (Takeichi, 1991). Cadherins are a superfamily of integral membrane glycoproteins that promote calcium-dependent cell adhesion. The first cadherins identified were named according to their tissue of origin: epithelial $(\mathrm{E})$, neural $(\mathrm{N})$ and placental $(\mathrm{P})$ cadherins (for a review, see Takeichi, 1995). E-cadherin is a $120 \mathrm{kDa}$

${ }^{*}$ Current address: Department of Animal and Dairy Sciences, College of Veterinary Medicine, Mississippi State University, MS 39762, USA

${ }^{+}$Correspondence

Email: bagnell@aesop.rutgers.edu transmembrane protein and was the first cadherin identified to have a role in mediating selective adhesion between epithelial cells (Yoshida-Noro et al., 1984). E-cadherin is expressed transiently during vertebrate development (Takeichi, 1991) and in adult reproductive tissue (Byers et al., 1994).

Although little is known about the factors controlling the expression of $\mathrm{E}$-cadherin in the embryo, there is evidence to support hormonal control of E-cadherin expression in reproductive tissues. Oestrogens promote growth of the reproductive tract and have been proposed as key regulators of E-cadherin in the adult female reproductive tract (Blaschuk and Farookhi, 1989). This proposal is based on the fact that oestradiol is a potent stimulator of Ecadherin expression in the mouse ovary (MacCalman et al., 1994a) and uterus (MacCalman et al., 1994b). Similarly, expression of E-cadherin in immature rat granulosa cells is stimulated by oestradiol in vitro (Blaschuk and Farookhi, 1989). In addition, progesterone induces expression of E-cadherin in mouse uterine epithelium (MacCalman et al., 1994b). Whether agents other than steroid hormones influence the expression of E-cadherin in the reproductive tract has not been investigated. Relaxin, a member of the insulin-like growth factor family, like oestradiol, promotes 
growth and remodelling of reproductive tissues. In pigs, relaxin stimulates uterine growth in pregnant (Galvin et al., 1991; Min et al., 1997), prepubertal (Hall et al., 1990) and ovariectomized steroid-treated animals (Hall et al., 1992). Relaxin also enhances growth of the uterus in several other species including rats, mice and Rhesus monkeys (for a review, see Sherwood, 1994). Relaxin increases cervical wet mass and protein (Wang-Lee et al., 1998), and promotes softening and dilation of the cervix at parturition (Kertiles and Anderson, 1979; O'Day et al., 1989). Of particular interest is the observation that relaxin increases proliferation, as well as E-cadherin expression, in the MCF7 mammary epithelial carcinoma cell line (Bani-Sacchi et al., 1994). Growth of reproductive tissue is the net result of mitogenic activity, as well as changes in cell-cell adhesion, which permit tissue expansion. Because of the growthpromoting and remodelling effects of relaxin in reproductive tissues, it was of interest to study the effect of relaxin on the expression of E-cadherin. Therefore, the objective of this study was to characterize the expression of E-cadherin during relaxin-induced growth and remodelling of the uterus and cervix in pigs. In particular, this study was designed using a prepubertal pig model to determine the effect of relaxin on the expression of E-cadherin in the reproductive tract, independent of high circulating steroids.

\section{Materials and Methods}

\section{Materials}

Purified pig relaxin (carboxymethyl A fraction (CMA) fraction; 3000 iu $\mathrm{mg}^{-1}$ ) was prepared in the Department of Biomedical Sciences (Ontario Veterinary College, University of Guelph, Guelph, ON) by extraction and purification from corpora lutea of pregnant sows, using the method of Sherwood and O'Byrne (1974). Purity was confirmed by SDS-PAGE analysis, which revealed a single band of approximately $6.2 \mathrm{kDa}$. Enhanced chemiluminescence kit (ECL) and X-ray film for protein (Hyperfilm$\mathrm{ECL}$ ) and mRNA (Hyperfilm-multipurpose (MP)) detection were obtained from Amersham (Arlington Heights, IL). Monoclonal mouse anti-human E-cadherin antibody, specific for the cytoplasmic domain of E-cadherin, was obtained from Transduction Laboratories (Lexington, KY) and rat anti-mouse uvomorulin (clone DECMA-1), which crossreacts with the extracellular domain of E-cadherin (Vestweber and Kemler, 1985), was obtained from Sigma Chemical Co. (St Louis, MO). Goat anti-mouse IgGhorseradish peroxidase conjugate (Transduction Laboratories) and a goat anti-mouse IgG-fluorescein isothiocyanate (FITC) conjugate (Zymed Laboratories, San Francisco, CA) were used for the detection of antigen-antibody complexes in protein extracts and tissue sections, respectively. TissueTek optimal cutting tissue (OCT) compound was purchased from Miles Laboratories (Elkhardt, IN). All other chemicals and molecular supplies were purchased from Sigma and Gibco-BRL Life Technologies (Gaithersburg, MD), respectively, unless otherwise stated.

\section{Animals and tissue collection}

Prepubertal (approximately 115 days old, $n=9$ ) Yorkshire-Landrace crossbred gilts housed at the Swine Unit of the New Jersey Agricultural Experiment Station (Rutgers University, New Brunswick, NJ) were injected i.m. with either purified pig relaxin $\left(0.5 \mathrm{mg}(0.5 \mathrm{ml})^{-1}, n=4\right)$ or saline $(n=4)$ at $6 \mathrm{~h}$ intervals for $54 \mathrm{~h}$ (Hall et al., 1990). Animals were killed by bolt-action stunning and exsanguination $3 \mathrm{~h}$ after the last injection. This animal experimental protocol was reviewed and approved by the Rutgers University Animal Care Advisory Committee. The uteri and cervices were removed, trimmed of fat, measured and weighed. Portions of uterine and cervical tissues from each animal were fixed in $4 \%(\mathrm{v} / \mathrm{v})$ formalin in PBS. The remaining tissue was frozen in liquid nitrogen and stored at $-80^{\circ} \mathrm{C}$. The trophic effects of relaxin on the uterus and cervix, and systemic and local (uterine fluid) concentrations of relaxin after administration in vivo in this animal model, have been reported (Hall et al., 1992; Ohleth et al., 1997). The prepubertal status of the gilts was confirmed by the absence of oestradiol in the plasma and uterine flushes of all animals before and after the treatment regimen (Ohleth et al., 1997). In addition, follicular oestradiol concentrations were an order of magnitude lower than those in cyclic animals.

Madin Darby canine kidney epithelial cells (MDCK, American Type Culture Collection, Rockville, MD) synthesize E-cadherin (Shore and Nelson, 1991), but there is no evidence of E-cadherin expression in skeletal muscle (Eidelman et al., 1989). Thus, MDCK epithelial cells and pig skeletal muscle were used as positive and negative controls, respectively, for detection of E-cadherin protein. Controls for northern blot analysis included total RNA from L-cells, a mouse fibroblast cell line deficient in E-cadherin, and Lcells transfected with a mouse E-cadherin gene (full-length cDNA of 436 base pairs) together with the gene for resistance to the antibiotic G418 (Nagafuchi et al., 1987). The normal L-cells and G418-resistant transformants were kindly provided by M. Steinberg (Princeton University, Princeton, NJ).

\section{Immunoblotting}

Protein was extracted from tissue samples as described by Ryan et al. (1996). Briefly, tissues were homogenized in boiling lysis buffer $(1.0 \mathrm{~g}$ in $5.0 \mathrm{ml} ; 1 \%(\mathrm{w} / \mathrm{v}) \mathrm{SDS}, 0.01 \mathrm{~mol}$ Tris- $\mathrm{HCl} \mathrm{I}^{-1}\left(\mathrm{pH}\right.$ 7.5), $0.001 \mathrm{~mol} \mathrm{CaCl}_{2} \mathrm{I}^{-1}$ ) and then heated in a microwave for $2 \times 5-7 \mathrm{~s}$ cycles at high power (approximately 650 watts). Samples were then sonicated to reduce viscosity and centrifuged $\left(12000 \mathrm{~g}, 15^{\circ} \mathrm{C}\right.$ for $\left.30 \mathrm{~min}\right)$ to remove insoluble material. Protein content was determined using a detergent-compatible protein assay kit (DC Protein Assay; Bio-Rad Laboratories, Melville, NY).

Protein samples $(20-50 \mu \mathrm{g})$ were separated by SDSPAGE under reducing conditions and transferred on to polyvinylidene difluoride membranes (Millipore, Bedford, MA). After blocking in 5\% (w/v) BSA in Tris-buffered saline 
(TBST, 0.01 mol Tris- $\mathrm{HCl} \mathrm{I}^{-1}(\mathrm{pH} 7.5), 0.1 \%$ (v/v) Tween20), membranes were probed with a mouse anti-human Ecadherin antibody in TBST-1\% (w/v) BSA $\left(0.2 \mu \mathrm{g} \mathrm{ml}^{-1}\right)$ for $1 \mathrm{~h}$ at room temperature or overnight at $4^{\circ} \mathrm{C}$. After they were washed with TBST $(6 \times 2 \mathrm{~min})$, blots were incubated with a goat anti-mouse IgG peroxidase-conjugated antibody $\left(0.2 \mu \mathrm{g} \mathrm{ml}^{-1}\right)$ for $1 \mathrm{~h}$ at room temperature. The antibodyantigen complexes were detected by enhanced chemiluminescence and exposure to Hyperfilm-ECL. Multiple exposures $(2-30 \mathrm{~s})$ were performed to maximize visualization of protein bands with minimal background. Protein size was determined by including prestained protein molecular mass markers $\left(14.3-200.0 \times 10^{-3}\right)$ in the gels.

\section{Isolation of RNA and northern blot analysis}

Total cellular RNA was extracted from tissue using the method of Cathala et al. (1983), with modifications as described by Koos (1995). In brief, tissue was homogenized in cold 4 mol guanidine isothiocyanate $\mathrm{I}^{-1}$ buffer and precipitated with five volumes of 4 mol $\mathrm{LiCl} \mathrm{I}^{-1}$ overnight at $4^{\circ} \mathrm{C}$. The precipitate was pelleted, redissolved in TES buffer (0.05 mol Tris- $\mathrm{HCl} \mathrm{l}^{-1}$ ( $\left.\mathrm{pH} 7.5\right), 0.005$ mol EDTA I-1, 0.5\% $(\mathrm{w} / \mathrm{v}) \mathrm{SDS})$ and digested with proteinase $\mathrm{K}\left(150 \mu \mathrm{g} \mathrm{ml} \mathrm{m}^{-1}\right)$ for $30 \mathrm{~min}$. The digests were extracted with phenol: chloroform: isoamyl alcohol, and were then precipitated in ethanol. Quantity and quality of RNA were determined by spectrophotometry at 260 and $280 \mathrm{~nm}$, respectively.

Total cellular RNA (20 $\mu \mathrm{g}$ per sample) and a molecular size marker (0.29-9.5 kb RNA ladder) were separated by electrophoresis in $1 \%(\mathrm{w} / \mathrm{v})$ agarose-formaldehyde gels, transferred on to charged nylon membranes (Nytran; Schleicher \& Schuell, Keene, NH) and prepared for hybridization as described by Ryan et al. (1996). A 2529 base pair mouse E-cadherin cDNA probe (provided by O. Blaschuk, McGill University, Montréal, PQ; Chen et al., 1991) was labelled with [ $\left.{ }^{32} \mathrm{P}\right]$-deoxy-CTP $\left(3000 \mathrm{Ci} \mathrm{mol}^{-1}\right.$; NEN, Boston, MA) by the random primer method (Feinberg and Vogelstein, 1983) to a specific activity of approximately $1 \times 10^{8}$ c.p.m. $\mu g^{-1}$. Hybridization was performed at $37^{\circ} \mathrm{C}$ for $30 \mathrm{~h}$ in prehybridization buffer containing heatdenatured salmon sperm DNA (final concentration of $0.2 \mathrm{mg} \mathrm{ml}^{-1}$ ) and the ${ }^{32} \mathrm{P}$-labelled E-cadherin probe $\left(5 \times 10^{6}\right.$ c.p.m. $\left.\mathrm{ml}^{-1}\right)$. After hybridization, membranes were washed twice in $2 \times$ sodium chloride, sodium phosphate, ethylenediamine tetracetic acid (SSPE) at room temperature for 5 min each, washed twice in $2 \times$ SSPE 1\% (w/v) SDS at $55^{\circ} \mathrm{C}$ (30 min each) and then washed twice with $0.2 \times \mathrm{SSPE}$ (30 min each). The blots were exposed to Hyperfilm-MP at $-80^{\circ} \mathrm{C}$ for $48 \mathrm{~h}$.

\section{Immunohistochemistry}

Frozen sections $(8-10 \mu \mathrm{m})$ of uterine and cervical tissues embedded in Tissue-Tek OCT compound were mounted on poly-L-lysine-coated slides. Tissue sections, MDCK epithelial cells and L-cells were fixed with cold acetone $(10 \mathrm{~min}$ at $-20^{\circ} \mathrm{C}$ ) and permeabilized with $0.2 \%$ (v/v) Triton-X100 in Tris-buffered saline (TBS, 0.01 mol Tris- $\mathrm{HCl} \mathrm{I}^{-1}, \mathrm{pH}$ 7.5) for $20 \mathrm{~min}$. Cells and tissue sections were then rinsed in TBS, blocked with $10 \%(\mathrm{v} / \mathrm{v})$ normal goat serum for $1 \mathrm{~h}$ and subsequently incubated with a mouse anti-human Ecadherin antibody $\left(5 \mu \mathrm{g} \mathrm{ml}^{-1}\right.$ in $5 \%(\mathrm{v} / \mathrm{v})$ normal goat serum-TBS) overnight at $4^{\circ} \mathrm{C}$. The specificity of E-cadherin fluorescence staining was confirmed by substituting nonimmune mouse ascites fluid with the primary antibody. The next morning, slides were washed in TBS $(3 \times 2$ min each), incubated with a goat anti-mouse IgG-FITC conjugate $(1: 100)$ in TBS-1\% normal pig serum for $1 \mathrm{~h}$. After the slides were washed in TBS $(3 \times 2 \mathrm{~min})$, they were mounted with coverslips using a gelatin and glycerol mounting agent $(2.0 \%(\mathrm{w} / \mathrm{v})$ gelatin, $5.0 \%(\mathrm{v} / \mathrm{v})$ glycerol, $0.05 \%(\mathrm{w} / \mathrm{v})$ azide in TBS) and viewed using an incident-light fluorescence microscope (G42-110-e Axioscop, Zeiss). All incubations were carried out in a humidified chamber at room temperature. Localization of E-cadherin in reproductive tissue was confirmed using another monoclonal antibody directed against mouse E-cadherin (uvomorulin: clone DECMA1; Vestweber and Kemler, 1985). As the results obtained from the present study using the anti-human Ecadherin and the anti-mouse uvomorulin were the same, data from only the anti-human E-cadherin studies are shown.

Assessment of uterine and cervical luminal epithelial growth was determined by measuring the height of the epithelial layer from the basal lamina to the apical surface using an ocular micrometer under a light microscope. Frozen tissue sections that were used for assessment were fixed in acetone, stained with haematoxylin and eosin, and then mounted with Permount. A minimum of ten sites (chosen at random) viewed under a $\times 20$ objective were measured on each uterine and cervical tissue section and the values were given in ocular units ( 1 unit $=40 \mu \mathrm{m}$, mean \pm SEM). Owing to the potential variation in the thickness of the cryosections and the plane of sectioning, quantitative analysis of E-cadherin immunofluorescence was not attempted on tissue samples (Bowen et al., 1996).

\section{Densitometry and statistical analysis}

Immunoblot and northern blot analyses were performed at least twice on uterine samples from four animals in each treatment group. Because of sample loss, cervical Ecadherin protein and mRNA analysis were performed using tissue from three animals per group. E-cadherin protein and mRNA expression were quantified by scanning densitometry (Ultroscan X; Pharmacia LKB Biotechnology Inc., Piscataway, NJ). Quantitative analysis of E-cadherin protein and mRNA concentrations are presented in densitometric units as mean \pm SEM. All E-cadherin immunoreactive bands were included in the quantitative analysis. For RNA analysis, uniformity of loading was checked and corrected for by using ethidium bromide staining of 28S RNA (Bonini and Hofmann, 1991). The data were analysed by ANOVA 
(a)

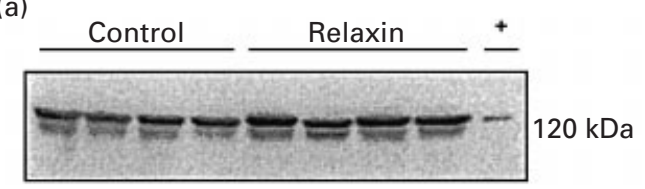

(b)

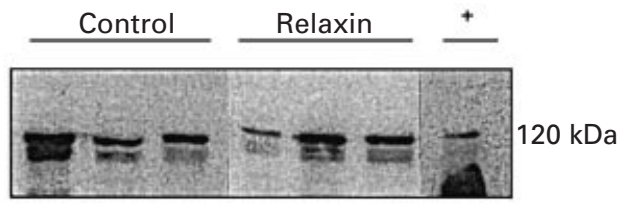

(d)

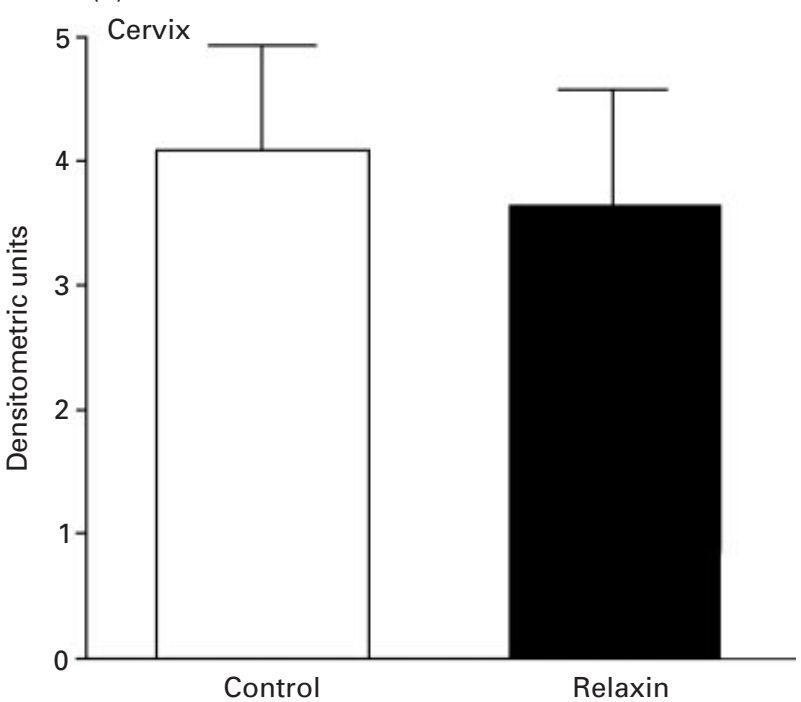

Fig. 1. Epithelial cadherin (E-cadherin) protein in the uterus and cervix of pigs after treatment in vivo with relaxin. Immunoblot analysis of E-cadherin in (a) uterine extracts and (b) cervical extracts. (c) Quantitative analysis of uterine E-cadherin protein ( $\square$ control, $n=4$; $\square$ relaxin-treated, $n=4)$. Values are mean \pm SE. (d) Quantitative analysis of cervical E-cadherin protein ( $\square$ control, $n=3$; $\square$ relaxin-treated, $n=3)$. Values are mean \pm SE. The molecular mass $(\mathrm{kDa})$ of the protein is indicated on the right. All E-cadherin immunoreactive bands were included in the quantitative analysis. Asterisk indicates significant difference $(P<0.05)$.

and differences were tested using Fisher's LSD. A value of $P<0.05$ was regarded as significant.

\section{Results}

\section{Immunoblot analysis}

A major $120 \mathrm{kDa}$ band corresponding to E-cadherin and a lower molecular mass (approximately $118 \mathrm{kDa}$ ) immunoreactive band were observed in the uterus (Fig. 1a) of both control and relaxin-treated gilts. Administration of relaxin in vivo increased immunoreactive E-cadherin protein in the uterus (Fig. 1a). Quantitative analysis of the E-cadherin immunoreactive bands revealed that expression of $\mathrm{E}$ cadherin in uterine tissue of relaxin-treated gilts was significantly greater $(P<0.05)$ than that in the control animals (Fig. 1c). In the cervix, E-cadherin immunoreactivity was detected as a $120 \mathrm{kDa}$ band and, similar to the uterus, lower molecular mass forms (approximately 97-118 kDa) were detected in samples from all animals (Fig. 1b). E-cadherin immunoreactivity was more variable in the cervix in comparison with the expression of uterine E-cadherin. No significant changes in total E-cadherin protein were observed in the cervix after relaxin treatment compared with control animals (Fig. 1d). The positive control, MDCK cells, showed a signal at $120 \mathrm{kDa}$, which corresponded to E-cadherin (Fig. 1a,b), whereas pig skeletal muscle (negative control) showed no E-cadherin immunoreactivity (data not shown).

\section{Northern blot analysis}

Relaxin significantly increased the expression of Ecadherin transcripts in uterine tissue $(P<0.05)$ compared with controls (Fig. 2a,c). Although a distinct signal for E-cadherin mRNA was evident in tissue from the cervix (Fig. 2b), there was no significant change in E-cadherin expression in these tissues in response to relaxin treatment (Fig. 2d). The G418-resistant L-cell transformants, transfected with the E-cadherin gene $(L+)$, served as a positive control for E-cadherin mRNA (Fig. 2a,b), although no transcript was detected in total RNA from normal L-cells (L-; Fig. 2b).

\section{Immunohistochemical localization of E-cadherin}

In the uterus, E-cadherin protein was localized in the glandular (Fig. 3b) and luminal epithelium (Fig. 3 a,c,d). However, there was no apparent difference in the intensity of E-cadherin staining in uterine tissue between control and 
(a)
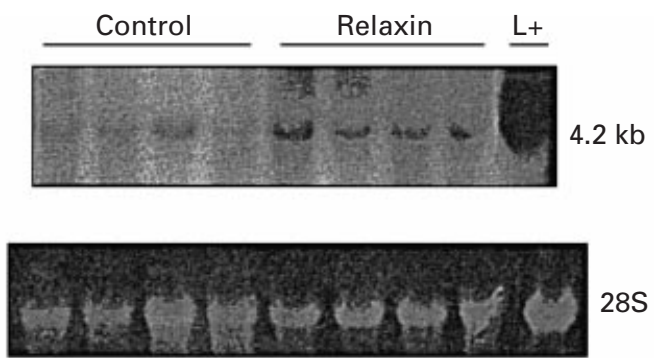

(c)

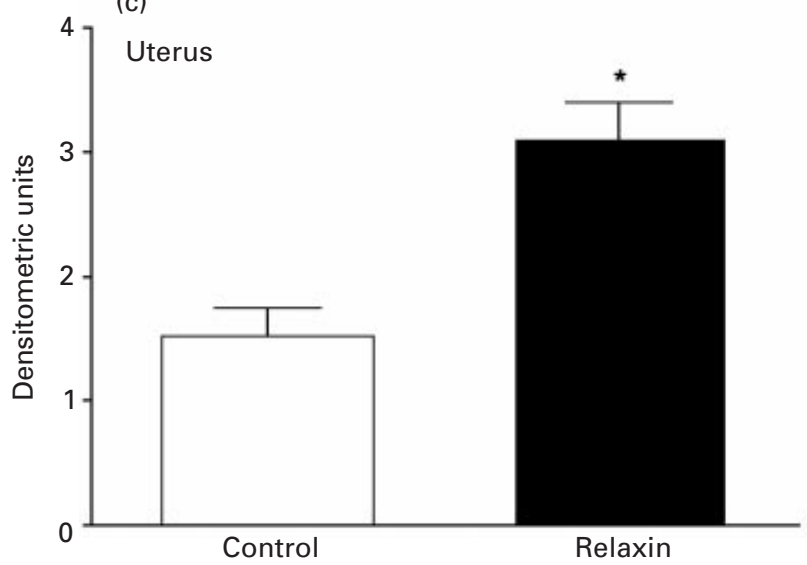

(b)
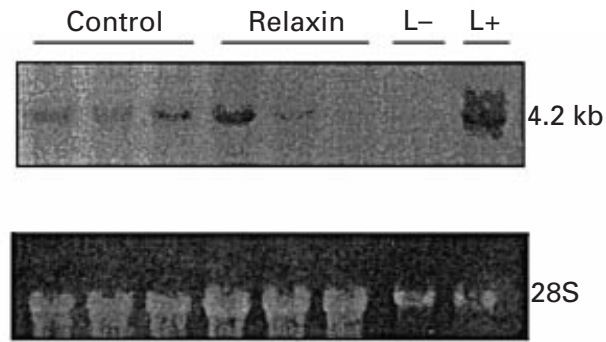

(d)

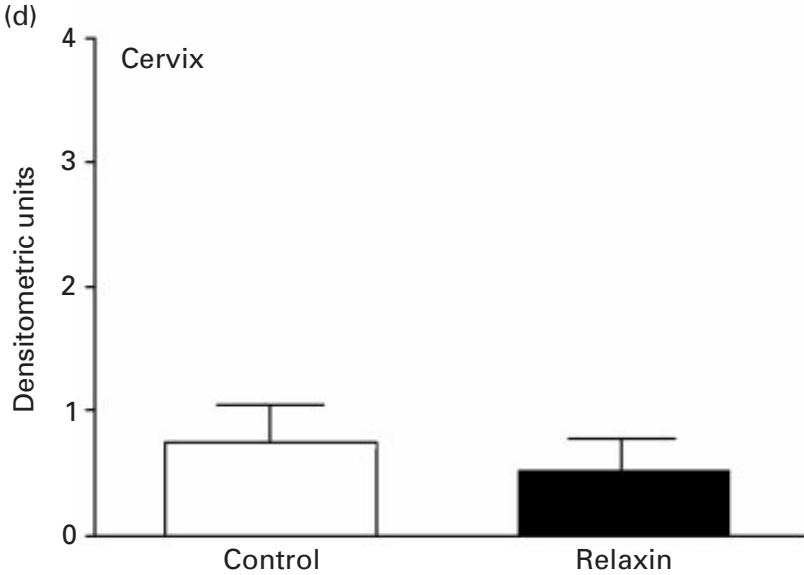

Fig. 2. Detection of epithelial cadherin (E-cadherin) mRNA in the uterus and cervix of pigs after treatment in vivo with relaxin. Northern blot analysis of (a) uterine total RNA and (b) cervical total RNA using a mouse cDNA E-cadherin probe. (c) Quantitative analysis of uterine E-cadherin mRNA expression ( $\square$ control, $n=4 ; \boldsymbol{\square}$ relaxin-treated, $n=4$ ). Values are mean \pm SE. (d) Quantitative analysis of cervical E-cadherin mRNA expression ( $\square$ control, $n=3$; $\square$ relaxin-treated, $n=3$ ). Values are mean \pm SE. G418-resistant L-cells deficient in E-cadherin ( $\mathrm{L}-$ ) served as a negative control. L-cells transfected with the E-cadherin gene ( $\mathrm{L}+$ ) served as a positive control. Transcript size is indicated on the right in kb. RNA loading was quantified by ethidium bromide staining of $28 \mathrm{~S}$ RNA. Asterisk indicates significant difference $(P<0.05)$.

relaxin-treated animals. In the uterus, E-cadherin was localized in glandular epithelial cells (Fig. 3b) whereas, in cervical tissues, only the luminal epithelium stained specifically for E-cadherin (data not shown). The height of the uterine luminal epithelium was measured from the basal lamina to the apical surface (Fig. $3 \mathrm{~d}$ ). In relaxin-treated gilts, the height of the uterine luminal epithelium was significantly greater $(P<0.05)$ compared with that of control animals (Fig. 4a), whereas relaxin treatment had no effect on the height of the cervical luminal epithelium (Fig. 4b). There was no immunofluorescent labelling of stroma or muscle tissue. Similarly, labelling was absent in sections in which non-immune mouse ascites fluid was substituted for the E-cadherin antibody. Transformed L-cells and MDCK epithelial cells stained for E-cadherin, whereas nontransformed L-cells showed no evidence of staining (data not shown).

\section{Discussion}

The present study investigated the effect of relaxin on E-cadherin expression during growth and remodelling of the uterus and cervix in prepubertal gilts. Although the presence of E-cadherin has been reported in reproductive tissues, this is the first study to describe E-cadherin expression in the pig reproductive tract and localization of Ecadherin protein to specific cells in the uterus and cervix of pigs. In the present study, relaxin-induced uterine growth was correlated with a significant increase in E-cadherin protein and mRNA. This response was independent of local or systemic steroids, as both oestradiol (Ohleth et al., 1997) and progesterone (Lenhart et al., 1999) were not detected in plasma or uterine flushes of the relaxin-treated animals. Although it is known that relaxin increases proliferation and E-cadherin expression in the MCF-7 human mammary cancer cell line (Bani-Sacchi et al., 1994), the present study was the first to provide evidence that relaxin increases E-cadherin expression in the uterus of any species. Furthermore, this increase in E-cadherin in response to relaxin is independent of circulating steroids. Collectively, these studies indicate that relaxin-induced growth of uterine and mammary cells is associated with an increase in Ecadherin expression.

The relaxin-induced increase in uterine E-cadherin protein and mRNA expression appears to be due to the increase in epithelial tissue growth that occurs in response 

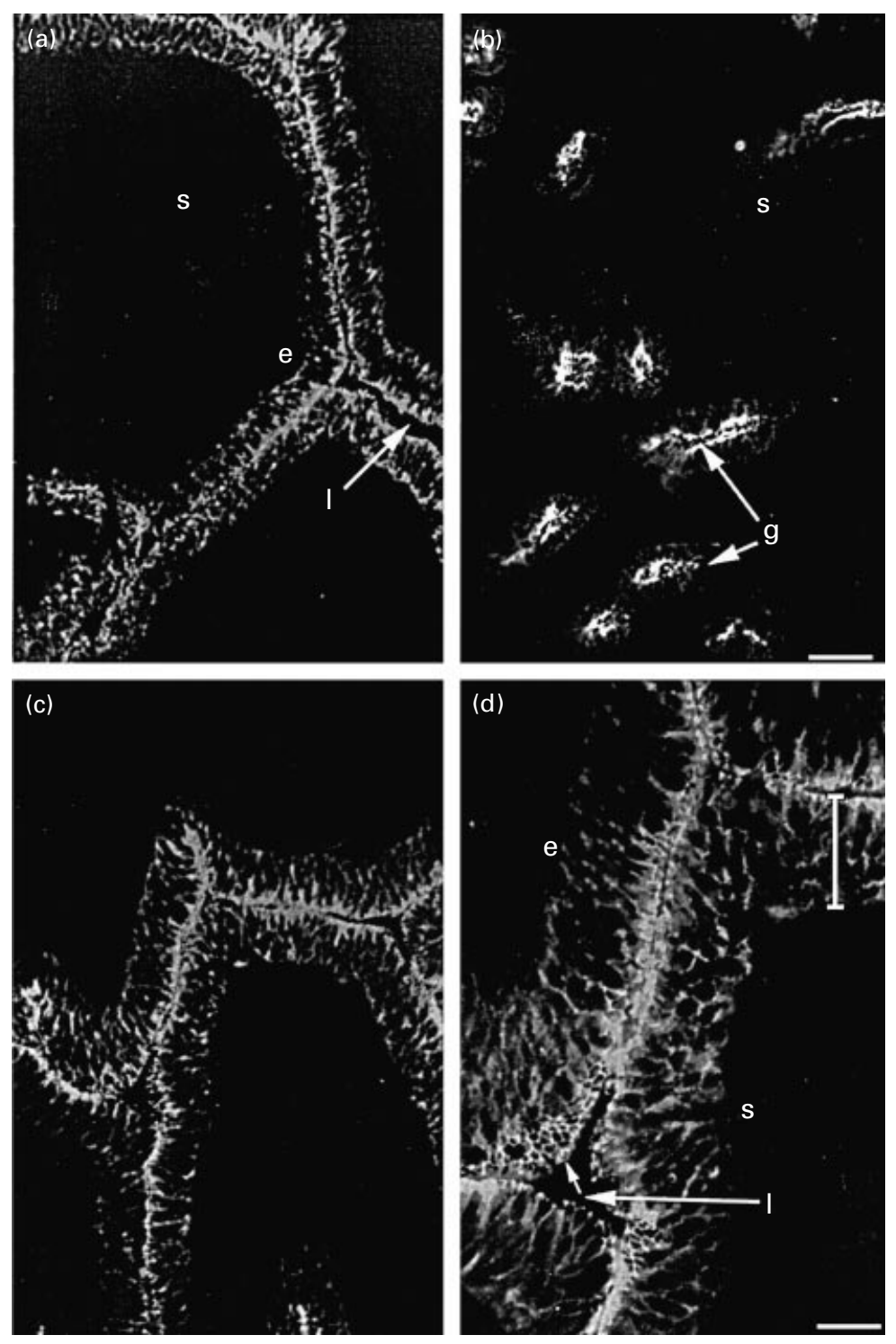

Fig. 3. Immunocytochemical localization of epithelial cadherin (E-cadherin) in the uterus of prepubertal gilts treated with relaxin. Uterine sections (approximately $8 \mu \mathrm{m}$ ) were incubated with anti-human E-cadherin antibody overnight at $4{ }^{\circ} \mathrm{C}$ and the antigen-antibody complex was visualized with an anti-mouse IgG-FITC conjugate. Immunolabelling of E-cadherin was localized in (a) the luminal epithelium of a control gilt; (b) glandular epithelium of a relaxin-treated gilt; and $(c, d)$ luminal epithelium of a relaxintreated gilt. The vertical bar defines the luminal epithelial layer from basal lamina to apical surface. Note the marked increase in the height of the luminal uterine epithelium evident in the relaxin-treated animal (d) Staining for Ecadherin is specific to the cell surface as seen in the oblique section of the epithelium (arrow). e: epithelium, g: gland, I: lumen, s: stroma. Scale bars represent (a,b,c) $60 \mu \mathrm{m}$ and (d) $28 \mu \mathrm{m}$.

to relaxin. Because E-cadherin is expressed in tissues of epithelial origin, an increase in the size and the number of uterine epithelial cells during growth would be expected to increase E-cadherin expression. For example, in the present study, relaxin-induced uterine growth resulted in a significant increase in luminal epithelial height, which contributed to an increase in the amount of E-cadherin detected. In rats, relaxin administration also increases 
(a)

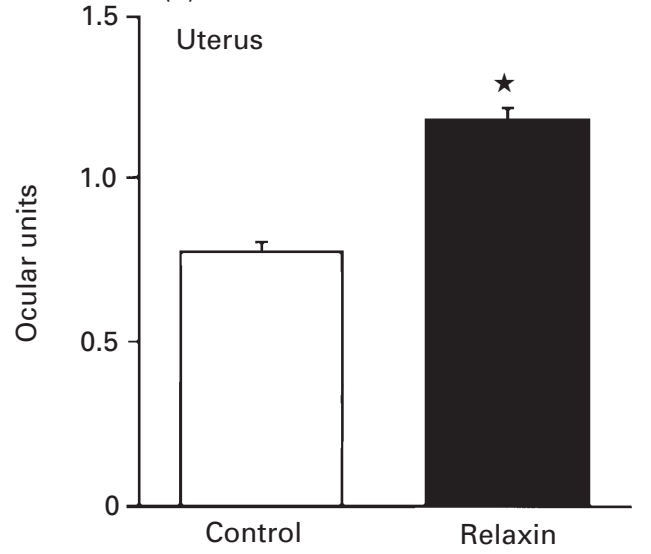

(b)

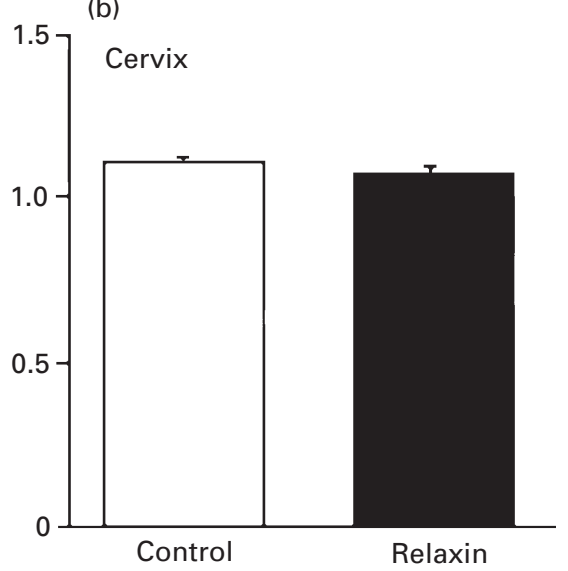

Fig. 4. Quantitative analysis of changes in the height of the luminal epithelium of the uterus and cervix from prepubertal gilts ( $\square$ control, $n=3$; $\square$ relaxin-treated, $n=3$ ) after relaxin treatment in vivo. Measurements were made (ten sites per section at random) along the luminal epithelial wall of (a) uterine and (b) cervical tissue sections. Values are mean $\pm \operatorname{SEM}(1$ ocular unit $=40 \mu \mathrm{m})$. Asterisk indicates significant difference $(P<0.05)$.

vaginal epithelial cell height, the number of epithelial cell layers and the total number of vaginal epithelial cells (Zhao and Sherwood, 1998). Administration of relaxin to pregnant rats contributed to cervical growth by promoting cervical epithelial cell proliferation (Burger and Sherwood, 1995). Similarly, Lee et al. (1992) reported that the density of cervical epithelial cells was reduced in relaxin-deficient pregnant rats compared with that of controls. The concept that epithelial cells are a target of relaxin action in reproductive tissue is supported by the localization of relaxin binding sites in epithelial cells of the cervix, mammary gland and nipple of pigs (Min and Sherwood, 1996). In addition, in the human uterus, relaxin binding was detected in both luminal and glandular epithelial cells (Kohsaka et al., 1998).

The localization of E-cadherin to the glandular and luminal epithelia of the pig endometrium and the absence of immunoreactive E-cadherin in the uterine stroma is consistent with the cellular distribution of E- and Pcadherins in the human uterus (Tabibzadeh et al., 1995; van der Linden et al., 1995). The similar pattern and intensity of E-cadherin immunostaining in the uterine and cervical epithelium of both control and relaxin-treated gilts indicates that E-cadherin is constitutively expressed in these tissues. Similarly, in human endometrial epithelium, it has been postulated that constitutive E-cadherin expression may have a role in the maintenance of epithelial architecture of the endometrium during both the proliferative and secretory phases of the oestrous cycle (van der Linden et al., 1995). In addition, the expression of $\mathrm{E}$ - and P-cadherins in the human endometrium is independent of the phase of the oestrous cycle, circulating oestrogen or progesterone concentrations, and expression of oestrogen or progesterone receptors (van der Linden et al., 1995). In contrast, both oestradiol and progesterone are reported to enhance E-cadherin transcription in the immature mouse uterus (MacCalman et al., 1994b). However, whether this increase in transcription results in an increase in translation and consequently $\mathrm{E}$ cadherin protein or whether it is due to endometrial epithelial cell growth in response to steroid administration has not been investigated.

Although relaxin treatment increased cervical wet mass and E-cadherin protein in the prepubertal gilt model used in the present study (Wang-Lee et al., 1998), there were no differences in the expression of cervical E-cadherin between control and relaxin-treated animals. In pregnant pigs, relaxin treatment increases cervical wet and dry masses (O'Day-Bowman et al., 1991); however, the effects of relaxin on the proliferation of cervical epithelial cells in pigs have not been reported. In rats, relaxin contributes to cervical growth by promoting epithelial cell proliferation (Burger and Sherwood, 1995). Thus, given that E-cadherin is expressed in epithelial cells, a change in E-cadherin expression would be expected to accompany the increase in pig cervical mass observed in response to relaxin. The absence of an effect of relaxin on the expression of cervical E-cadherin is most likely explained by the fact that the pig cervix consists primarily of extracellular matrix and smooth muscle (Winn et al., 1992), and not E-cadherin-expressing epithelial tissue. The relaxin-induced increase in pig cervical mass is primarily due to increased water uptake (Hall et al., 1990) and the changes in pig cervical epithelial cell proliferation were too small to be detected in the present study.

In summary, the present study is the first to report Ecadherin expression in the pig uterus and cervix. In addition, these studies support the hypothesis that relaxininduced growth of the uterus involves changes in E- 
cadherin expression. The increase in pig uterine epithelial tissue growth that occurs in response to relaxin was accompanied by an increase in both E-cadherin mRNA and protein. However, relaxin did not have a significant effect on the expression of E-cadherin in the pig cervix. There is a growing body of evidence that cadherin-mediated adhesion is important for the structural integrity and growth of reproductive tissues (for a review, see Rowlands et al., 2000). Given the importance of uterine tissue growth and remodelling during the oestrous cycle, implantation and pregnancy, further studies on the control of cellular adhesion, including the expression of cadherins and other adhesion molecules, are important for a better understanding of uterine growth and function.

The authors thank M. Steinberg, Department of Molecular Biology, Princeton University, Princeton, NJ, for the E-cadherin transfected and non-transfected L cells; O. Blaschuk, Department of Surgery, McGill University, Montréal, PQ, for the E-cadherin cDNA probe; and J. Pleva, Department of Animal Sciences, Rutgers University for preparation of the figures. This research was supported by the USDA (No. 93-37203-8979), the GH Cook Undergraduate Honors Program and the New Jersey Agricultural Experiment Station.

\section{References}

Bani-Sacchi L, Bani D, Brandi ML, Falchetti A and Bigazzi M (1994) Relaxin influences growth, differentiation and cell-cell adhesion of human breast cancer cells in culture International Journal of Cancer $\mathbf{5 7}$ 129-134

Blaschuk OW and Farookhi R (1989) Estradiol stimulates cadherin expression in rat granulosa cells Developmental Biology 136 564-567

Bonini JA and Hofmann C (1991) A rapid, accurate, nonradioactive method for quantitating RNA on agarose gels Biotechniques 11 708-709

Bowen JA, Bazer FW and Burghardt RC (1996) Spatial and temporal analyses of integrin and Muc-1 expression in pig uterine epithelium and trophoectoderm in vivo. Biology of Reproduction 55 1098-1106

Burger LL and Sherwood OD (1995) Evidence that cellular proliferation contributes to relaxin-induced growth of both the vagina and cervix in the pregnant rat Endocrinology 136 4820-4826

Byers SW, Sujarit S, Jegou BN, Butz S, Hoschutzky H, Herrenknecht K, MacCalman C and Blaschuk OW (1994) Cadherins and cadherinassociated molecules in the developing and maturing rat testis Endocrinology 134 630-639

Cathala G, Savouraet J-F, Mendez B, West BL, Karin M, Martial JA and Baxter JD (1983) A method for isolation of intact, translationally active ribonucleic acid DNA 2 329-335

Eidelman S, Damsky CH, Wheelock MH and Dmajanov I (1989) Expression of the cell-cell adhesion glycoprotein cell-CAM 120/80 in normal human tissues and tumors American Journal of Pathology 153 101-110

Feinberg AP and Vogelstein B (1983) A technique for radiolabeling DNA restriction endonuclease fragments to high specific activity Annals of Biochemistry 132 6-13

Galvin JLM, Anthony RV and Day BN (1991) Effects of purified pig relaxin on the uterus of gilts during early pregnancy Animal Reproduction Science 26 293-301

Hall JA, Cantley TC, Day BN and Anthony RV (1990) Uterotrophic actions of relaxin in prepubertal gilts Biology of Reproduction 42 769-774

Hall JA, Cantley TC, Galvin JM, Day BN and Anthony RV (1992) Influence of steroids on relaxin-induced uterine growth in ovariectomized gilts Endocrinology 1340 3159-3166

Hynes RO (1992) Integrins: versatility, modulation and signaling in cell adhesion Cel/ 69 11-25
Kertiles LP and Anderson LL (1979) Effect of relaxin on cervical dilation, parturition and lactation in the pig Biology of Reproduction 21 57-68

Kohsaka T, Min G, Lukas G, Trupin S, Campbell E and Sherwood OD (1998) Identification of specific relaxin-binding cells in the human female Biology of Reproduction 59 991-999

Koos RD (1995) Increased expression of vascular endothelial growth/ permeability factor in the rat ovary following an ovulatory gonadotropin stimulus: potential roles in follicle rupture Biology of Reproduction $\mathbf{5 2}$ 1426-1435

Lee AB, Hwang J-J, Haab LM, Fields PA and Sherwood OD (1992) Monoclonal antibodies specific for rat relaxin. VI. Passive immunization with monoclonal antibodies throughout the second half of pregnancy disrupts histological changes associated with cervical softening at parturition in rats Endocrinology 130 2386-2391

Lenhart JA, Ryan PL, Kathleen KM, Ohleth KM and Bagnell CA (1999) Expression of connexin-26, -32 and -43 gap junction proteins in the pig cervix and uterus during pregnancy and relaxin-induced growth Biology of Reproduction 61 1452-1459

MacCalman CD, Farookhi R and Blaschuk OW (1994a) Estradiol regulates E-cadherin mRNA levels in the surface epithelium of the mouse ovary Clinical Experimental Metastasis 12 276-282

MacCalman CD, Farookhi R and Blaschuk OW (1994b) Estradiol and progesterone regulate $\mathrm{E}$-cadherin mRNA levels in the mouse uterus Endocrine Journal 2 485-490

Min G and Sherwood OD (1996) Identification of specific relaxin-binding cells in the cervix, mammary glands, nipples, small intestine and skin of pregnant pigs Biology of Reproduction 55 1243-1252

Min G, Hartzog MG, Jennings RL, Winn RJ and Sherwood OD (1997) Evidence that endogenous relaxin promotes growth of the vagina and uterus during pregnancy in gilts Endocrinology 138 560-565

Nagafuchi A, Shirayoshi Y, Okazaki K, Yahuda K and Takeichi M (1987) Transformation of cell adhesion properties by exogenously introduced E-cadherin cDNA Nature 329 341-343

O'Day M, Winn R, Easter R, Dziuk P and Sherwood O (1989) Hormonal control of the cervix in pregnant gilts. II. Relaxin promotes changes in the physical properties of the cervix in ovariectomized hormone-treated pregnant gilts Endocrinology 125 3004-3010

O'Day-Bowman M, Winn R, Dziuk P, Lindley E and Sherwood O (1991) Hormonal control of the cervix in pregnant gilts. III. Relaxin's influence on cervical biochemical properties in ovariectomized hormone-treated pregnant gilts Endocrinology 129 1967-1976

Ohleth KM, Lenhart JA, Ryan PL, Radecki SV and Bagnell CA (1997) Relaxin increases insulin-like growth factors (IGFs) and IGF-binding proteins of the pig uterus in vivo. Endocrinology 138 3652-3658

Rowlands TM, Symonds M, Farookhi R and Blaschuk OW (2000) Cadherins: crucial regulators of structure and function in reproductive tissues Reviews of Reproduction 5 53-61

Ryan PL, Valentine A and Bagnell CA (1996) Expression of E-cadherin in the developing and adult pig ovary Biology of Reproduction 55 1091-1097

Sherwood OD (1994) Relaxin. In The Physiology of Reproduction pp 861-1009 2nd Edn Eds E Knobil and JD Neill. Raven Press, New York

Sherwood OD and O'Byrne EM (1974) Purification and characterization of pig relaxin Archives of Biochemistry and Biophysics 160 185-196

Shore EM and Nelson WJ (1991) Biosynthesis of the cell adhesion molecule Uvomorulin (E-cadherin) in Madin Darby canine kidney epithelial cells Journal of Biological Chemistry 226 19 672-19 680

Tabibzadeh S, Babaknia A, Kong QF, Zupi E, Marconi D, Romanini C and Satyaswaroop PG (1995) Menstruation is associated with disordered expression of desmoplakin I/II and cadherin/catenins and conversion of $\mathrm{F}$ to G-actin in endometrial epithelium Human Reproduction 10 776-784

Takeichi M (1991) Cadherin cell adhesion receptors as a morphogenetic regulator Science 22 1451-1455

Takeichi M (1995) Morphogenetic roles of classic cadherins Current Opinion in Cell Biology 7 619-627

van der Linden PJ, de Goeij AF, Dunselman GA, Erkens HW and Evers JL (1995) Expression of cadherins and integrins in human endometrium throughout the menstrual cycle Fertility and Sterility $\mathbf{6 3} 1210-1216$

Vestweber D and Kemler R (1985) Identification of a putative cell adhesion domain of uvomorulin EMBO Journal 4 3393-3398 
Wang-Lee JL, Lenhart JA, Ohleth KM, Ryan PL and Bagnell CA (1998) Regulation of urokinase- and tissue-type plasminogen activator by relaxin in the uterus and cervix of the prepubertal gilt Journal of Reproduction and Fertility 114 119-125

Winn RJ, O'Day-Bowman MB and Sherwood OD (1992) Hormonal control of the cervix in pregnant gilts. IV. Relaxin promotes changes in the histological characteristics of the cervix that are associated with cervical softening during late pregnancy in gilts Endocrinology 133 121-128

Yoshida-Noro C, Suzuki N and Takeichi M (1984) Molecular nature of the calcium-dependent cell-cell adhesion system in mouse teratocarcinoma and embryonic cells studied with a monoclonal antibody Developmental Biology 101 19-27
Zhao S and Sherwood OD (1998) Monoclonal antibodies specific for rat relaxin. X. Endogenous relaxin induces changes in the histological characteristics of the rat vagina during the second half of pregnancy Endocrinology 139 4726-4734

Received 6 June 2001.

First decision 12 July 2001.

Accepted 2 August 2001. 